\title{
Clinical and Histopathological Relevance of Helicobacter pylori BabA2 Genotype
}

\author{
Tariq Elhashim ${ }^{\mathrm{a}}$, M. Imad Mustafa Mahmud ${ }^{\mathrm{a}}$, Nasser Amjad ${ }^{\mathrm{b}}$, Norra Harun ${ }^{\mathrm{c}}$ and Imad M. Alani ${ }^{\mathrm{a}}$ \\ ${ }^{a}$ Department of Basic Medical Sciences, International Islamic University Malaysia, Kuantan 25710, Pahang, \\ Malaysia \\ ${ }^{b}$ Department of Surgery, International Islamic University Malaysia, Kuantan 25710, Pahang, Malaysia \\ 'Department of Pathology, Hospital Tengku Ampuan Afzan, 25100 Kuantan, Pahang, Malaysia
}

\begin{abstract}
Introduction: $H$. pylori BabA is an outer membrane protein that mediates bacterial adherence to the gastric epithelium, triggers several pathways during the course of infection, and thus contributes to the disease development. Considering the variability in the presence of BabA coding gene (babA2) among $\mathrm{H}$. pylori clinical strains, the aim of this study was to assess the relationship between the genotype status of $H$. pylori babA2 and the severity of clinical and histopathological outcomes. Methods: Gastric mucosal biopsy specimens were collected from 30 CLO test-positive patients, 16 with gastritis and 14 with peptic ulcer disease. Polymerase chain reaction was carried out to detect the presence of $\mathrm{H}$. pylori-specific glmM gene and BabA coding gene (babA2). Histopathological examination was performed to evaluate the severity of $H$. pylori-associated gastric disease according to the Updated Sydney Classification System. Results: The glmM and $b a b A 2$ genes were present in $100 \%$ and $86.7 \%$ of the tested $H$. pylori strains, respectively. Although higher degrees of inflammatory activity and $H$. pylori density were noted in babA2-positive biopsy specimens, there was no statistically significant association between $b a b A 2$ genotype status and the severity of gastric disease. Conclusion: The babA2 genotype status of $H$. pylori may not be considered as a sole marker for determining the infection outcomes.
\end{abstract}

Keywords: Helicobacter pylori; babA2; Gastritis; Peptic ulcer; Histopathology

\section{INTRODUCTION}

H. pylori is a spiral-shaped Gram-negative organism that uniquely colonizes the human stomach and induces a persistent inflammation. Gastric colonization with $H$. pylori is associated with a wide spectrum of gastric diseases, including gastritis, peptic ulcer, non-ulcer dyspepsia, and gastric cancer. ${ }^{1}$ The risk of developing any of these disorders in the presence of $H$. pylori infection depends on several bacterial, host, and environmental factors that relate to the type and severity of gastric disease. ${ }^{2}$

H. pylori genome encodes for a large set of outer membrane proteins (OMP) that contribute to the pathogenicity of the bacteria. The variable expression of these proteins among $H$. pylori clinical strains may confer a selective advantage to certain

Corresponding author:

Prof. Dr. Mohammed Imad Al-Deen Mustafa Mahmud

Department of Basic Medical Sciences, Kulliyyah of Medicine

International Islamic University Malaysia

25200 Kuantan, Pahang, Malaysia

Email: imad@iium.edu.my

Telephone No. 006095714491 strains in different hosts. ${ }^{3,4}$ Therefore, the genotype of $H$. pylori is a potentially useful predictor of the clinical outcomes of gastric mucosal colonization. $\mathrm{H}$. pylori blood group antigen-binding adhesin $\mathrm{A}$ (BabA) is a surface protein encoded by babA2 gene. It mediates binding to the fucosylated Lewis $b$ (Leb) blood group antigen, and to the terminal fucose residues of $A, B$, and $O$ blood group antigens, that are expressed on the gastric mucosa. ${ }^{5-7}$ BabAmediated binding to Leb antigen on the gastric epithelial surface triggers the production of the proinflammatory cytokines (CCL5 and IL-8) and the precancer-related factors (CDX2 and MUC2) ${ }^{8}$, and induces DNA double strand breaks (DSB) and DNA damage response in host cells. ${ }^{9}$

A number of studies have shown that babA2-positive strains are highly associated with increased risk of developing severe mucosal injury and adverse clinical outcomes. However, the correlation between babA2 genotype status and infection outcomes does not seem to be universal. ${ }^{10}$ The babA2-positive status has been linked to severe gastric atrophy and intestinal metaplasia in patients in the United states of America (USA) and Colombia. ${ }^{11}$ Conversely, babA2 genotype status was not associated with any of the clinical outcomes of $H$. pylori infection in Thai patients. ${ }^{12}$ 
The inconsistency among different reports underscores the importance of further investigations for elucidating the clinical and histopathological relevance of $H$. pylori babA2 genotype status. This study aimed to correlate between $H$. pylori babA2 genotype status and the clinical and histopathological findings in Malaysian patients.

\section{MATERIALS AND METHODS}

\section{Study description:}

This is a laboratory based cross sectional investigation of the clinical and histopathological relevance of $H$. pylori babA2 genotype status. Endoscopy was performed to visualize the gastric mucosal abnormalities, and to collect 3 biopsy specimens from each patient. CLO test was used in conjunction with endoscopy to diagnose $H$. pylori infection. Conventional and molecular procedures were performed to isolate the organism, confirm its identity and to identify its babA2 genotype status. Histopathological examination was carried out to evaluate the severity of $H$. pylori-associated disease. The study protocol was reviewed and granted ethical approvals by International Islamic University Malaysia Research Ethics Committee (IREC), and the Ministry of Health Malaysia at the Institute for Medical Research (IMR).

\section{Study participants:}

This study was conducted on 30 consecutive CLO test-positive patients who attended the Endoscopy Unit, Department of Surgery, Hospital Tengku Ampuan Afzan (HTAA), Kuantan, Pahang, Malaysia, from $15^{\text {th }}$ January 2015 to $30^{\text {th }}$ June 2015 . Patients who had received nonstreroidal anti-inflammatory drugs, antibiotics, H2-receptor blockers or proton pump inhibitors (PPI) within two weeks prior to endoscopy were excluded from the study. The endoscopic findings of patients were recorded as either gastritis, or peptic ulcer disease. Three gastric mucosal biopsy specimens were obtained from each patient for CLO test, bacterial isolation, and histopathological examination.

Initial diagnosis of $H$. pylori infection:

Campylobacter-like organism (CLO) test (KimberlyClark, Roswell, GA, USA) was performed in conjunction with the endoscopy procedure according to the manufacturers' instructions. One gastric biopsy specimen was immediately embedded into the CLO test medium after collection. A positive result was reported if the colour changed from yellow to red within 24 hours (usually within 1 hour) of incubation at room temperature. CLO testpositive gastric biopsy specimens were stored at $70^{\circ} \mathrm{C}$ in normal saline until DNA extraction was performed.

Isolation of $\boldsymbol{H}$. pylori clinical strains:

One gastric biopsy specimen collected during the endoscopy was immediately placed in a Bijou bottle containing $3 \mathrm{ml}$ of semi-solid Stuart's
Transport Medium (Thermo Scientific Microbiology, Melaka, Malaysia). The bottle was then sealed in a plastic bag and kept chilled during transport to the laboratory in a polystyrene box containing pre-frozen freezer bricks.

The biopsy specimen was transferred from the transport medium to a Petri dish, and it was teased and minced in a drop of saline using a scalpel to release the bacteria from the mucosal surface. The bacterial suspension was then spread over the whole surface of a plate of $H$. pylori selective medium containing Columbia agar, Dent's antibiotic mixture, and $7 \%$ horse blood (Thermo Scientific Microbiology, Melaka, Malaysia).

The inoculated plate was incubated at $37^{\circ} \mathrm{C}$ under microaerobic conditions generated by CampyGen Compact pouch system (Oxoid, Basingstoke, UK). The plate was inspected after 5-7 days for the presence of the typical tiny translucent $H$. pylori colonies. Suspected colonies were identified and confirmed as H. pylori if spiral or curved Gram-negative, ureasepositive, catalase-positive, and oxidase-positive organisms were present.

A single colony of the isolated $H$. pylori was picked from the primary culture and sub-cultured using the same medium and incubation conditions mentioned above for purification. Multiple bacterial colonies were harvested from each secondary culture plate, and stored at $-70^{\circ} \mathrm{C}$ in Tryptone Soy Broth with $15 \%$ glycerol (Thermo Scientific Microbiology, Melaka, Malaysia) until DNA extraction was performed.

\section{Detection of glmM and $b a b A 2$ genes:}

Genomic DNA was extracted from 2 sources, $H$. pylori colonies harvested from the secondary culture plate and CLO test-positive gastric biopsy specimen obtained from the assay medium. Extraction was performed using PureLink Genomic DNA Mini Kit (Invitrogen, Carlsbad, CA, USA) according to the manufacturer's instructions. Extracted DNA was stored at $-70^{\circ} \mathrm{C}$ until amplification reaction was performed.

PCR was performed to confirm the presence of $H$. pylori-specific glmM gene and to determine the babA2 genotype status using primer sets described previously $^{12-13}$ (Table I). Amplification was performed in a total volume of $25 \mu \mathrm{l}$. The reaction mixture contained $12.5 \mu \mathrm{l}$ of $2 \mathrm{x}$ Taq Master Mix (Bioron, Ludwigshafen, Germany), $1 \mu \mathrm{l}$ of $5 \mu \mathrm{M}$ babA2 or 12.5 $\mu \mathrm{M}$ glmM forward and reverse primers (Bio Basic, Ontario, Canada), $5 \mu \mathrm{l}$ of template DNA, and $5.5 \mu \mathrm{l}$ of sterile deionized water. Amplification was carried out using GeneAmp PCR System 9700 automated thermal cycler (PE Applied Biosystems, Singapore) under the thermal cycling conditions described previously $^{12-13}$ (Table I). 
DNA extracted from $H$. pylori reference strain $J 99$ (ATCC 700824) was used as a positive control, and deionized distilled water was used as a non-template negative control. The positive and negative controls

Table I. Primers sets and thermal cycling conditions

\begin{tabular}{|c|c|c|c|c|}
\hline Gene & Primer* & $\begin{array}{l}\text { Nucleotide } \\
\text { sequence } \\
\left(5^{\prime}-3^{\prime}\right)\end{array}$ & Product & $\begin{array}{l}\text { Amplification } \\
\text { conditions }\end{array}$ \\
\hline \multirow[t]{2}{*}{$g \operatorname{lmM}$} & glmM-F & $\begin{array}{l}\text { AA- } \\
\text { GCTTTTAG } \\
\text { GGGTGTTA } \\
\text { GGGGTTT }\end{array}$ & \multirow[t]{2}{*}{294 bp } & \multirow[t]{2}{*}{$\begin{array}{l}93^{\circ} \mathrm{C}, 1 \mathrm{~min} ; \\
55^{\circ} \mathrm{C}, 1 \mathrm{~min} ; \\
72^{\circ} \mathrm{C}, 1 \mathrm{~min} \\
(35 \text { cycles })\end{array}$} \\
\hline & glmM-R & $\begin{array}{l}\text { AA- } \\
\text { GCTTACTTT } \\
\text { CTAACACTA } \\
\text { ACGC }\end{array}$ & & \\
\hline \multirow[t]{2}{*}{$b a b A 2$} & $b a b A 2-\mathrm{F}$ & $\begin{array}{l}\text { CCAAAC- } \\
\text { GAAACAAAA } \\
\text { AGCGT }\end{array}$ & \multirow[t]{2}{*}{271 bp } & \multirow{2}{*}{$\begin{array}{l}94^{\circ} \mathrm{C}, 1 \mathrm{~min} ; \\
45^{\circ} \mathrm{C}, 1 \mathrm{~min} ; \\
72^{\circ} \mathrm{C}, 1 \mathrm{~min} \\
(30 \text { cycles })\end{array}$} \\
\hline & babA2-F & $\begin{array}{l}\text { GCTTGTG- } \\
\text { TAAAAGCC } \\
\text { GTCGT }\end{array}$ & & \\
\hline
\end{tabular}

${ }^{*} \mathrm{~F}$ : Forward primer, R: Reverse primer

The PCR product was electrophoresed on $2 \%$ agarose gel stained with ethidium bromide. Electrophoresis was conducted at a constant voltage of $80 \mathrm{~V}$ for 50 minutes using PowerPac Basic electrophoresis apparatus (Bio-Rad, CA, USA). The gel was visualized and photographed using Gel Doc System (Bio-Rad, CA, USA). The presence of 294 bp and 271 bp sized bands indicated a positive genotype status of $\mathrm{g} / \mathrm{mM}$, babA2 genes, respectively.

\section{Gastric histopathological examination:}

One biopsy specimen from each patient was fixed in $10 \%$ formalin, embedded in paraffin, and cut in sequential $5 \mu \mathrm{m}$ sections. The obtained sections were stained with Modified Giemsa stain to detect the presence of $H$. pylori, and Hematoxylin and Eosin (H\&E) stain to evaluate the inflammatory cells infiltrate and the mucosal abnormalities. Slides were examined by a single, experienced pathologist who was blinded to the patient's clinical presentation, endoscopic findings, and CLO test result.

The slides were evaluated according to the Updated Sydney Classification System as described previously. ${ }^{14,15}$ A semi-quantitative scoring of 5 morphological variables, including $H$. pylori density, neutrophil activity, mononuclear cell infiltration, glandular atrophy, and intestinal metaplasia, was made based on a standard visual analogue scale graded from 0 , indicating the normal status, up to 3 , indicating the maximal intensity (Table II).
Table II. Definition and grading guideline for each of the histological variables according to the Updated Sydney Classification System

\begin{tabular}{|c|c|}
\hline Variable & Grading guideline* \\
\hline $\begin{array}{l}\text { Density of } H . \text { pylori } \\
\text { colonization: } \\
\text { Density of } H . \text { pylori } \\
\text { overlying the epithelium }\end{array}$ & $\begin{array}{l}\text { 0: No } H \text {. pylori } \\
\text { 1: Scattered } H \text {. pylori covering } \\
<1 / 3 \text { of the surface } \\
\text { 2: Moderate colonization covering } \\
1 / 3 \text { to } 2 / 3 \text { of the surface } \\
\text { 3: Dense colonization covering }>2 / 3 \\
\text { of the surface }\end{array}$ \\
\hline $\begin{array}{l}\text { Degree of inflammatory } \\
\text { activity: } \\
\text { Infiltration of PMN in } \\
\text { the gastric mucosa }\end{array}$ & $\begin{array}{l}\text { 0: No PMN infiltration } \\
\text { 1: Scattered PMN infiltrating }<1 / 3 \text { of } \\
\text { the mucosa } \\
\text { 2: Moderate PMN infiltrating } 1 / 3 \text { to } \\
2 / 3 \text { of the mucosa } \\
\text { 3: Marked PMN infiltrating }>2 / 3 \text { of } \\
\text { the mucosa }\end{array}$ \\
\hline $\begin{array}{l}\text { Degree of chronic } \\
\text { inflammatory infiltrate: } \\
\text { Infiltration of } \\
\text { Mononuclear cells } \\
\text { (lymphocytes, plasma } \\
\text { cells) in the gastric } \\
\text { mucosa }\end{array}$ & $\begin{array}{l}\text { 0: Normal mononuclear cells level } \\
\text { (up to 5/HPF) } \\
\text { 1: Mild increase in mononuclear } \\
\text { cells (6-10/HPF) } \\
\text { 2: Moderate increase in } \\
\text { mononuclear cells (I0-20/HPF) } \\
\text { 3: Diffuse increase in mononuclear } \\
\text { cells (>20/HPF) }\end{array}$ \\
\hline $\begin{array}{l}\text { Degree of glandular } \\
\text { atrophy: } \\
\text { Loss of specialized } \\
\text { gastric glandular tissue }\end{array}$ & $\begin{array}{l}\text { 0: No atrophy } \\
\text { 1: Few gastric glands are lost } \\
\text { 2: Up to } 50 \% \text { of gastric glands are } \\
\text { lost } \\
\text { 3: More than } 50 \% \text { of gastric glands } \\
\text { are lost }\end{array}$ \\
\hline $\begin{array}{l}\text { Degree of intestinal } \\
\text { metaplasia: } \\
\text { The amount of gastric } \\
\text { glandular tissue } \\
\text { replaced by } \\
\text { intestinal-type } \\
\text { epithelium }\end{array}$ & $\begin{array}{l}\text { 0: No intestinal metaplasia } \\
\text { 1: Few glands are replaced by } \\
\text { intestinal cells } \\
\text { 2: Up to } 50 \% \text { of glands are } \\
\text { replaced by intestinal cells } \\
\text { 3: More than } 50 \% \text { of glands are } \\
\text { replaced by intestinal cells }\end{array}$ \\
\hline
\end{tabular}

* If areas with widely different grades were present on the same specimen, an average grade was considered after a general evaluation of the specimen.

PMN: Polymorphonuclear Cells; HPF: High Power Field (x40 objective)

\section{Statistical analysis:}

Chi-square and Fisher's exact tests were used to evaluate the association between $H$. pylori babA2 genotype status and the clinical outcomes. MannWhitney $U$ test was used to determine the relationship between $H$. pylori babA2 genotype status and the severity of different histopathological variables. A p-value of less than 0.05 was considered statistically significant. Calculations were performed using IBM SPSS Statistics software version 23 (IBM Corporation, NY, USA).

\section{RESULTS}

\section{Study population:}

A total of $30 \mathrm{H}$. pylori positive patients, 16 with gastritis and 14 with peptic ulcer, were recruited in our study. Patients were from different ethnic groups comprising 16 Malay (12 males and 4 females, with age range of 19 to 73 years and mean age of 44 years), 6 Chinese ( 2 males and 4 females, with age 
range of 25 to 72 years and mean age of 48 years), 6 Indians ( 3 males and 3 females, with age range of 34 to 73 years and mean age of 51 years), and 2 other males, 26 and 34 years old. The relatively low number of Chinese patients in this study may reflect the racial distribution of the Malaysian population with Malays predominance especially in and around Kuantan. Also many Chinese patients, being wealthier, attend the private health sector rather than the government health facilities.

Data showed that more Chinese patients had peptic ulcer disease compared to Malay and Indian patients. Males and females were nearly equally distributed among the different clinical outcomes. The mean age

Table III. Distribution of patients with different clinical outcomes according to race, gender, and age

\begin{tabular}{cccc}
\hline & \multicolumn{2}{c}{ Clinical status } & \\
\cline { 2 - 3 } Criteria & $\begin{array}{c}\text { Gastritis } \\
(n=16)\end{array}$ & $\begin{array}{c}\text { Peptic } \\
\text { ulcer } \\
(n=14)\end{array}$ & Total \\
\hline Ethnic group & $9(56.3 \%)$ & $7(50.0 \%)$ & $16(53.3 \%)$ \\
Malay & $2(12.5 \%)$ & $4(28.6 \%)$ & $6(20.0 \%)$ \\
Chinese & $3(18.8 \%)$ & $3(21.4 \%)$ & $6(20.0 \%)$ \\
Indian & $2(12.5 \%)$ & $0(0.0 \%)$ & $2(6.7 \%)$ \\
Others & & $9(64.3 \%)$ & $19(63.3 \%)$ \\
Gender & $10(62.5 \%)$ & $11(36.7 \%)$ \\
Male & $6(37.5 \%)$ & $5(35.7 \%)$ & \\
Female & & & $19-73$ \\
Age (years) & $19-73$ & $23-73$ & 45 \\
Range & 42 & 49 & \\
Mean & & & \\
\hline
\end{tabular}

\section{Detection of $H$. pylori infection:}

The initial diagnosis of $H$. pylori infection was made using CLO test. In which, a positive $H$. pylori status was indicated by a colour change from yellow to red. In culture, $H$. pylori was identified based on its colonial morphology (small translucent colonies), Gram staining (spiral or curved Gram-negative rods), and biochemical activity (positive urease, catalase, and oxidase tests). The identity of $H$. pylori was further confirmed by detecting the presence of species-specific glmM gene in both, CLO testpositive gastric biopsies and bacterial isolates. A 294 bp segment of glmM gene was successfully detected in all tested biopsies and isolates (Figure I).

\section{Clinical relevance of babA2 genotype status:}

$H$. pylori babA2 genotype status was determined by conventional PCR amplification and visualization of a 271 bp segment of the babA2 gene (Figure II).
Overall, the babA2 genotype $H$. pylori was positive in $86.7 \%(26 / 30)$ of the studied patients. The babA2 gene was almost equally frequent in $H$. pylori strains of all disease groups. The frequency of babA2 gene in specimens obtained from gastritis patients and peptic ulcer patients was $81.2 \%$ (13/16) and $92.9 \%(13 / 14)$, respectively. There was no statistically significant difference between the above patients' groups (Table IV).

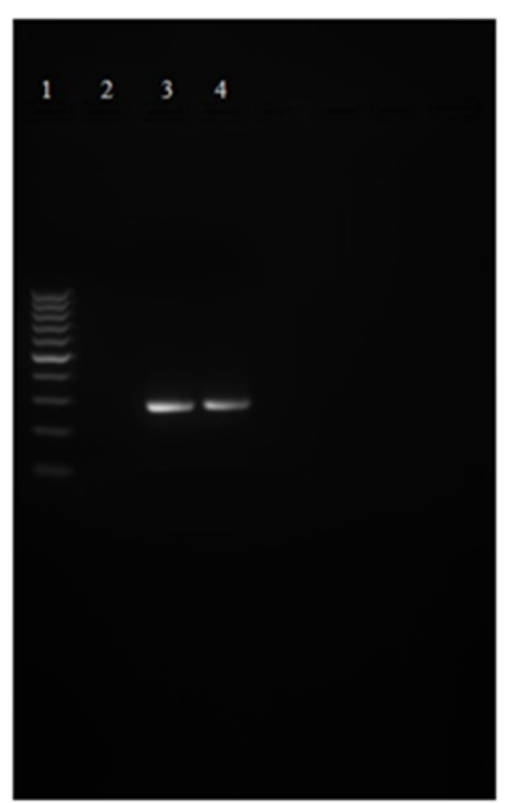

Figure I. Detection of $H$. pylori-specific glmM gene. Lane 1: 100 bp DNA Ladder; lane 2: negative control; lane 3: positive control; lane 4: tested specimen.

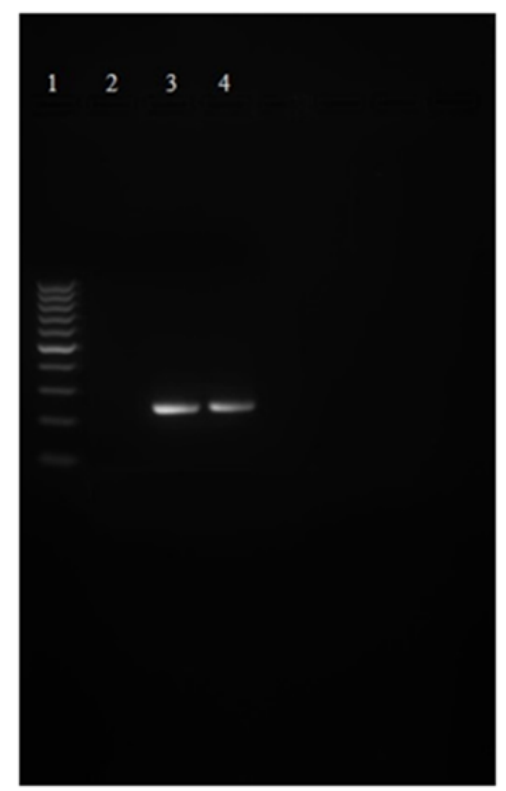

Figure II. Detection of $H$. pylori babA2 genotype status. Lane 1: 100 bp DNA Ladder; Lane 2: Negative control; Lane 3: Positive control; Lane 4: Tested specimen. 


\section{Histopathological relevance of babA2 genotype} status:

A semi-quantitative scoring of 5 morphological variables was performed according to the Updated Sydney Classification System (Figure III). In general, mild $H$. pylori density, moderate granulocytic and lymphocytic infiltration, and absent gastric atrophy and intestinal metaplasia were the most frequently encountered patterns during grading (Figure IV).
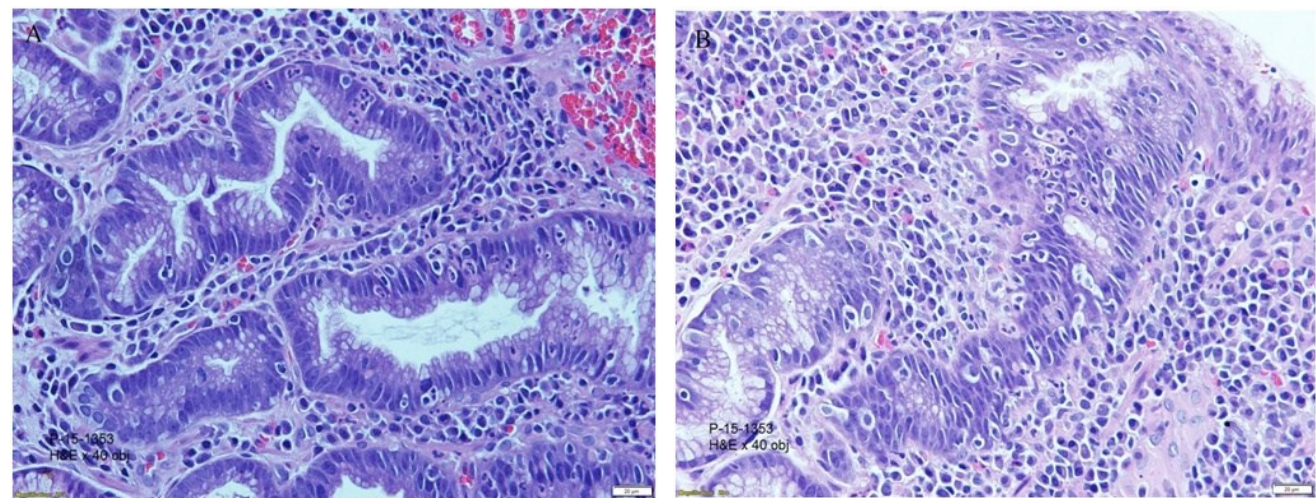

Figure III. Semi-quantitative scoring of histopathological findings according to the Updated Sydney Classification System. Selected gastric mucosal biopsy specimens with different patterns of histopathological findings were presented. A: Moderate neutrophilic infiltration in the lamina propria and glandular epithelium (H\&E, x400). B: Severe lymphocytic infiltration in the lamina propria (H\&E, x400).

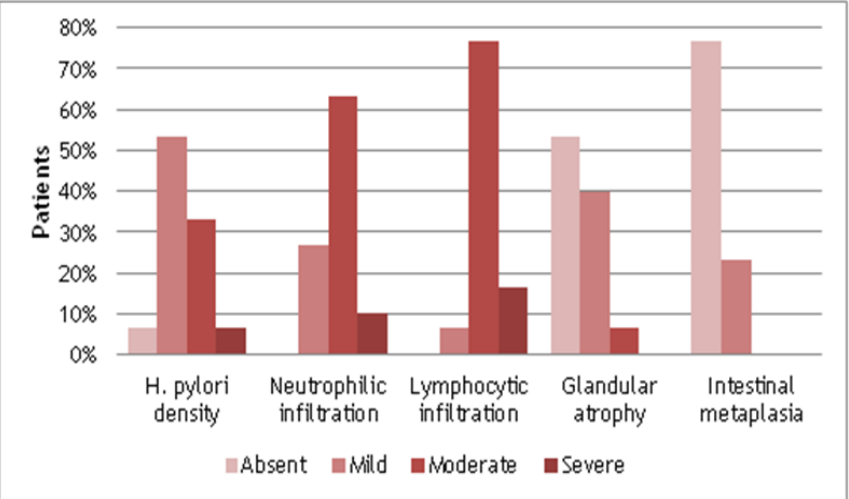

Figure IV. Distribution of patients according to the severity of gastric inflammation. Mild $H$. pylori density was observed in $53 \%$ of the examined gastric biopsy specimens. Moderate granulocytic and lymphocytic infiltration was reported in $63 \%$ and $77 \%$ of cases, respectively. Severe gastric atrophy and intestinal metaplasia was not recorded for any of the studied cases.

The average score of $H$. pylori colonization density was slightly higher in patients infected with babA2positive strains than in patients infected with babA2negative strains; however, the difference was not statistically significant. The babA2-positive status was associated with a higher degree of inflammatory activity.

A moderate to severe grade of PMN infiltration was observed in the majority of patients infected with babA2-positive strains, whereas no severe infiltration was found in those infected with babA2-negative strains; however, the associations did not reach to a statistically significant level. Conversely, the babA2 genotype status had no effect on the degree of lymphocytic infiltration, glandular atrophy, or intestinal metaplasia (Table V).
Table V. Relationship between $H$. pylori babA2 genotype status and gastric mucosal histopathology

\begin{tabular}{|c|c|c|c|}
\hline \multirow{2}{*}{$\begin{array}{l}\text { Histopathological } \\
\text { findings* }\end{array}$} & \multicolumn{2}{|c|}{ babA2 genotype status } & \multirow{2}{*}{$\stackrel{p}{p}$} \\
\hline & $\begin{array}{c}\text { Positive } \\
(n=26)\end{array}$ & $\begin{array}{l}\text { Negative } \\
\quad(n=4)\end{array}$ & \\
\hline $\begin{array}{l}\text { H. pylori } \\
\text { density }\end{array}$ & $1.42(0-3)$ & $1.25(1-2)$ & 0.635 \\
\hline $\begin{array}{l}\text { Neutrophilic } \\
\text { infiltration }\end{array}$ & $1.88(1-3)$ & $1.50(1-2)$ & 0.224 \\
\hline $\begin{array}{l}\text { Lymphocytic } \\
\text { infiltration }\end{array}$ & $2.12(1-3)$ & $2.00(1-3)$ & 0.710 \\
\hline $\begin{array}{l}\text { Glandular } \\
\text { atrophy }\end{array}$ & $0.54(0-2)$ & $0.50(0-1)$ & 1.000 \\
\hline $\begin{array}{l}\text { Intestinal } \\
\text { metaplasia }\end{array}$ & $0.27(0-2)$ & $0.25(0-1)$ & 0.934 \\
\hline
\end{tabular}

* Scores of histopathological findings were presented in mean (range)

** The $p$ value was determined by Mann-Whitney $U$ test

\section{DISCUSSION}

Several studies have shown that babA2-positive strains are closely associated with increased risk of developing more severe clinical and histopathological outcomes. However, the relationship between $H$. pylori babA2 genotype status and the severity of gastric mucosal damage does not seem to be universal. In the current study, we investigated the presence of babA2 gene in $30 \mathrm{H}$. pylori clinical strains, and evaluated the relationship between the babA2 genotype status and the clinical and histopathological outcomes of the infection.

We found that babA2 gene was present in $86.7 \%$ of the tested $H$. pylori strains, and there was no significant association between babA2 genotype status and the severity of gastric disease. 
Our findings are in agreement with several previous investigations performed in different geographical regions and failed to correlate between babA2 genotype status and any specific disease outcomes or mucosal changes. However, some other studies have successfully confirmed the association between babA2 genotype status and infection outcomes. For instance, babA2-positive strains has been shown to be more commonly associated with peptic ulcer and gastric cancer in Germany, ${ }^{16}$ peptic ulcer in India, ${ }^{17}$ severe intestinal metaplasia and gastric atrophy in US and Columbia. ${ }^{11}$ Conversely, reports from Japan, ${ }^{18}$ Korea, ${ }^{10}$ China, $^{19}$ Thailand, ${ }^{12}$ Brazil, ${ }^{20}$ and France ${ }^{21}$ have found no clinical or histopathological relevance of babA2 genotype status. This inconsistency between different studies indicates that there are probably important geographical variations.

\section{CONCLUSION}

In conclusion, our data represent the first report of the clinical and histopathological relevance of $H$. pylori babA2 genotype status in Malaysian patients. The babA2 gene was present in the majority of studied strains, and there was no influence of babA2 genotype status on the severity of gastric disease. Our findings suggest that $b a b A 2$ gene may not be considered as a sole marker for determining the infection outcomes.

It is more probable that multiple bacterial factors contribute to the differential outcome of $H$. pylori infection. Therefore, it is necessary to consider multiple virulence factors in the prediction of the severity of disease. Additionally, it is important to define what other multiple environmental and host factors that may influence the response to infection and determine the progression of gastritis to peptic ulcer disease or gastric cancer.

The conclusion from this study is limited by the relatively small size of the study population comprising 30 patients. This limitation might have led to inconclusive analysis of some data. This was due to constraints related to unexpected cut off of proposed research funds. Hence a bigger study should be carried out to confirm or negate the association.

\section{Conflict of Interest:}

The authors declare no potential conflicts of interests.

\section{REFERENCES}

1. Makola D, Peura DA, Crowe SE. Helicobacter pylori infection and related gastrointestinal diseases. Journal of clinical gastroenterology 2007; 41(6):548-58.

2. Sgouros SN, Bergele C. Clinical outcome of patients with Helicobacter pylori infection: the bug, the host, or the environment? Postgraduate Medical Journal 2006; 82(967):338-42.

3. Oleastro M, Ménard A. The Role of Helicobacter pylori Outer Membrane Proteins in Adherence and Pathogenesis. Biology 2013; 2(3):1110-34.

4. Backert S, Clyne M, Tegtmeyer N. Molecular mechanisms of gastric epithelial cell adhesion and injection of CagA by Helicobacter pylori. Cell communication and signaling : CCS 2011; 9:28.

5. Hage N, Howard T, Phillips C, Brassington C, Overman R, Debreczeni J, Gellert P, Stolnik $\mathrm{S}$, Winkler $\mathrm{G} \mathrm{S}$ and Falcone $\mathrm{F} \mathrm{H}$. Structural basis of Lewisb antigen binding by the Helicobacter pylori adhesin BabA. Sci. Adv. 2015; $1: \mathrm{e} 1500315$

6. Aspholm-Hurtig M, Dailide G, Lahmann M, Kalia $A$, Ilver $D$, Roche $N$ et al. Functional adaptation of BabA, the $H$. pylori ABO blood group antigen binding adhesin. Science (New York, N.Y.) 2004; 305(5683):519-22.

7. Ilver D, Arnqvist A, Ogren J, Frick IM, Kersulyte D, Incecik ET et al. Helicobacter pylori adhesin binding fucosylated histo-blood group antigens revealed by retagging. Science (New York, N.Y.) 1998; 279(5349):373-7.

8. Ishijima N, Suzuki M, Ashida H, Ichikawa $Y$, Kanegae $Y$, Saito I et al. BabA-mediated adherence is a potentiator of the Helicobacter pylori type IV secretion system activity. The Journal of biological chemistry 2011; 286(28):25256-64.

9. Toller IM, Neelsen KJ, Steger M, Hartung ML, Hottiger MO, Stucki M et al. Carcinogenic bacterial pathogen Helicobacter pylori triggers DNA double-strand breaks and a DNA damage response in its host cells. Proceedings of the National Academy of Sciences of the United States of America 2011; 108(36):14944-9.

10. Fujimoto S, Olaniyi Ojo O, Arnqvist A, Wu JY, Odenbreit S, Haas R et al. Helicobacter pylori BabA expression, gastric mucosal injury, and clinical outcome. Clin Gastroenterol Hepatol 2007; 5(1):49-58.

11. Yamaoka Y, Ojo O, Fujimoto S, Odenbreit $S$, Haas R, Gutierrez $O$ et al. Helicobacter pylori outer membrane proteins and gastroduodenal disease. Gut 2006; 55(6):775-81.

12. Chomvarin C, Namwat W, Chaicumpar K, Mairiang P, Sangchan A, Sripa B et al.

Prevalence of Helicobacter pylori vacA, cagA, cagE, ice $A$ and babA2 genotypes in Thai dyspeptic patients. International journal of infectious diseases : IJID : official publication of 
the International Society for Infectious Diseases 2008; 12(1):30-6.

13. Sheu B, Sheu $S$, Yang $H$, Huang $A$, Wu J. Host gastric Lewis expression determines the bacterial density of Helicobacter pylori in babA2 genopositive infection. Gut 2003; 52(7):927-32.

14. Chen XY, van Der Hulst, R W, Bruno MJ, van Der Ende, A, Xiao SD, Tytgat GN et al. Interobserver variation in the histopathological scoring of Helicobacter pylori related gastritis. J Clin Pathol 1999; 52(8):612-5.

15. Dixon MF, Genta RM, Yardley JH, Correa P. Classification and grading of gastritis. The updated Sydney System. International Workshop on the Histopathology of Gastritis, Houston 1994. Am J Surg Pathol 1996; 20(10):1161-81.

16. Gerhard M, Lehn N, Neumayer N, Boren T, Rad $\mathrm{R}$, Schepp $\mathrm{W}$ et al. Clinical relevance of the Helicobacter pylori gene for blood-group antigen-binding adhesin. Proc Natl Acad Sci U S A 1999; 96(22):12778-83.

17. Saxena A, Shukla S, Prasad KN, Ghoshal UC. Virulence attributes of Helicobacter pylori isolates \& their association with gastroduodenal disease. Indian J Med Res 2011; 133:514-20.

18. Mizushima $T$, Sugiyama $T$, Komatsu $Y$, Ishizuka $\mathrm{J}$, Kato M, Asaka M. Clinical relevance of the babA2 genotype of Helicobacter pylori in Japanese clinical isolates. J Clin Microbiol 2001; 39(7):2463-5.

19. Yu J, Leung WK, Go, M Y Y, Chan, M C W, To $\mathrm{KF}, \mathrm{Ng}, \mathrm{E} \mathrm{K} \mathrm{W}$ et al. Relationship between Helicobacter pylori babA2 status with gastric epithelial cell turnover and premalignant gastric lesions. Gut 2002; 51(4):480-4.

20. Mattar R, dos Santos, Anibal Ferreira, Eisig JN, Rodrigues TN, Silva FM, Lupinacci RM et al. No correlation of babA2 with vacA and cagA genotypes of Helicobacter pylori and grading of gastritis from peptic ulcer disease patients in Brazil. Helicobacter 2005; 10(6):601-8.

21. Lehours P, Menard A, Dupouy S, Bergey B, Richy $F$, Zerbib $F$ et al. Evaluation of the association of nine Helicobacter pylori virulence factors with strains involved in low-grade gastric mucosa-associated lymphoid tissue lymphoma. Infect Immun 2004; 72(2):880-8. 